\title{
Improving Science Learning Outcomes Through Student Team Achievement Division (STAD)
}

\section{Luh Monik Septiani Dewi ${ }^{1}$, I Made Citra Wibawa ${ }^{2}$, I Gusti Ayu Tri Agustiana ${ }^{3}$}

${ }^{123}$ Primary School Teacher Education Study Program, Ganesha University of Education, Singaraja, Bali, Indonesia

\begin{tabular}{l} 
A R T I C L E I N F O \\
\hline Article history: \\
Received 2 Juni 2020 \\
Received in revised form \\
12 Juli 2020 \\
Accepted 10 Agustus 2020 \\
Available online 28 Agustus \\
2020 \\
\hline kata kunci: \\
STAD, hasil \\
belajar IPA \\
keywords: \\
STAD, learning outcomes, \\
science
\end{tabular}

\begin{abstract}
A B S T R A K
Rendahnya hasil belajar siswa pada kompetensi Ilmu Pengetahuan Alam banyak dialami oleh siswa. Penyebab menurunnya hasil belajar IPA yaitu kecintaan guru terhadap satu metode pembelajaran dan penggunaan model pembelajaran yang kurang tepat sehingga siswa sulit dalam memahami pembelajaran, kurangnya komunikasi dan partisipasi antara peserta didik yang menyebabkan peserta didik kurang berani dalam bertanya dan berpendapat sehingga pembelajaran kurang maksimal, peserta didik masih kurang disiplin selama pembelajaran berlangsung. Berdasarkan uraian tersebut adapun tujuan penelitian ini adalah untuk mengetahui pengaruh yang signifikan model Kooperatif Tipe STAD Terhadap Hasil Belajar IPA. Penelitian ini menggunakan rancagan non-equivalent post-test only control group desigen dengan teknik intact group random sampling. Total popoulasi penelitian ini adalah 95 orang siswa dan total sampel pada penelitian ini berjumlah 49 orang siswa. Metode yang digunakan berupa tes dengan instrumen pilihan ganda berjumlah 20 butir soal. Data yang didapatkan
\end{abstract} dianalisis menggunakan analisis statistik deskriptif dan analisis inferensial dengan uji normalitas sebaran data, uji homogenitas varian (Uji-F) dan uji hipotesis (uji-t) menggunakan rumus polled varians. Hasil analisis data menggunkan uji-t diproleh thitung 2,540 Sedangkan $t_{\text {tabel }}$ dengan $\mathrm{db}=47$ sebesar 2,067 dengan taraf signifikansi $5 \%$. Hasil penelitian menunjukan terdapat pengaruh yang signifikan hasil belajar IPA kelompok siswa yang dibelajarkan dengan model kooperatif tipe $S T A D$ dengan kelompok siswa yang tidak dibelajarkan dengan model kooperatif tipe STAD. Model kooperatif tipe STAD menjadikan siswa sebagai pusat dalam pembelajaran melalui penerapan model kooperatif tipe STAD siswa termotivasi untuk bersaing dalam memahami pelajaran, melatih kemempuan dalam mengemukakan pendapat, disiplin dan bertanggung jawab atas diri sendiri dan kelompok.

\section{A B S T R A C T}

The low student learning outcomes of Science competencies are experienced by many students. The causes of the decline in science learning outcomes are the teacher's love for one learning method and the use of inadequate learning models so that students find it difficult to understand learning, lack of communication and participation between students which causes students to be less courageous in asking and arguing so learning is not optimal, students still lacking discipline during learning takes place. Based on the description, the purpose of this study is to determine the significant effect of the STAD Cooperative Model on Science Learning Outcomes. This study uses the design of a non-equivalent post-test only control group design with an intact group random sampling technique. The total population of this study was 95 students and the total sample in this study amounted to 49 students. The method used is a test with multiple-choice instruments totaling 20 items. The data obtained were analyzed using descriptive statistical analysis and inferential analysis with data distribution normality test, variant homogeneity test ( $F$-Test), and hypothesis testing ( $t$-test) using the pooled variance formula. The results of data analysis using the $t$-test obtained by $t_{\text {-count }} 2.540$ while the table with $d b=47$ of 2.067 with a significance level of $5 \%$. The results showed that there was a significant influence on the learning outcomes of science groups of students who were taught with the STAD type cooperative model with groups of students who were not taught with the STAD type cooperative model. The STAD type cooperative model makes students the center of learning through the application of the STAD type cooperative model students are motivated to compete in understanding lessons, train women in expressing opinions, discipline and take responsibility for themselves and the group.

\section{Introduction}

Student achievement in Indonesia has decreased in three competencies, namely mathematics competence, reading ability, and science competence (IPA). Data from Trends in International Mathematics and Science Study in 2015, especially Elementary Schools in Indonesia, obtained an average score of 397 so that Indonesia was ranked the fourth lowest of 43 countries. The latest data

Copyright (C) Universitas Pendidikan Ganesha. All rights reserved.

${ }^{1}$ Corresponding author.

E-mail addresses: monikseptiani.id04@gmail.com (Monik) ${ }^{1}$, imadecitra.wibawa@undiksha.ac.id (Citra) ${ }^{2}$

triagustiana.pgsdundiksha@gmail.com (Tri) ${ }^{3}$ 
regarding student achievement achievements can be seen based on the results of the achievement of the Organization of Economic Co-operation and Development (OECD, Program for International Student Assessment (PISA) and the Ministry of Education and Culture) that scientific competence in Indonesia this year gets an average score of 403 and has fulfilled ranked 3rd from the bottom of the 72 participating countries (Indriani, 2019). This statement is in line with Setiawati's opinion, (2019) that the quality of learning in elementary schools still needs to be improved. In connection with improving the quality of learning in schools, many efforts have been made to improve the quality and quality of education include improving the curriculum, running the teacher certification program, being active in conducting training and counseling for teachers, improving learning facilities, and infrastructure, even the government is aggressively implementing character education programs. But in reality, the government is trying to make it happen. the result is not in accordance with expectations. This is also supported based on the results of interviews, document studies, and observations with the principal and the homeroom teacher conducted on 22-24 October 2019 that there is 1) The love of teachers for one learning method, 2) When the learning process takes place, students, only listen, take notes, and working on the questions given by the teacher, 3) Students have difficulty mastering the concept of learning, 4) Student interaction during learning is not optimal due to students' lack of courage in asking and arguing 5) Lack of communication and participation between students, 6) Students are still less disciplined during learning.

These facts arise because of the weak mastery of learning models by some teachers, teachers find it difficult to apply the appropriate model so that when learning takes place students only focus on listening to, and recording information from the teacher, and in forming groups of students tend to only want to be with close friends. so that the interaction that occurs only with close friends this causes a sense of boredom and boredom by some students and causes uproar. Based on document notes regarding science learning outcomes, it is stated that student learning outcomes have not reached the minimum completeness criteria (KKM) or are still categorized as low. This fact can occur because the teacher does not master and understand the model to be applied in learning. In group formation, students are still given the freedom to choose their groups so that students will choose their closest friends to join to form groups, this will harm students this can form passive groups in learning because students with the same abilities gather with students who have the same ability. If this continues, it will be difficult for students to develop and improve their learning outcomes. These problems can be overcome by applying a cooperative-based model that is oriented to cooperation, namely the STAD type cooperative learning model. According to Popiyanto, (2020) that homo homini socius is a philosophy of cooperative learning model in education, this philosophy underlies that humans as social beings can adapt to their environment. In this learning model students are divided into groups, each group consisting of 4-5 heterogeneous people, there are six learning steps in the STAD cooperative model, this statement is supported by Nurdyansyah \& Fahyuni, (2016: 66) that the learning model Cooperative Type STAD consists of six syntaxes, namely, (a) Delivery of goals and motivation, (b) Group division, (c) Presentations from teachers, (d) Learning activities in teams (Teamwork), (e) Quizzes (Evaluation), (f) Team Achievement Award.

The STAD cooperative learning model focuses on activities and interactions between students to motivate and assist in mastering lessons to obtain maximum achievement (Sutinah, 2017). This opinion is in line with Nikmah, (2019) the STAD type cooperative learning model emphasizes collaboration in groups, this can provide opportunities for students to share experiences and opinions and motivate each other The learning process will be more interesting if there is a cooperation between students and students so that students with low skills can obtain knowledge and information from students who have higher expertise so that the learning process is more useful and students Do not feel bored to take part in learning in the classroom. This statement is in line with Karacop's opinion (2017) that cooperative learning has a positive impact on student academic achievement and social skills development, so this model is suitable to be applied because in this model students will be required to actively collaborate, participants will be more motivated in learning and able to convey opinions (Andrian, 2020). The cooperative model type STAD can actively find learning resources with peers, cooperative learning emphasizes team learning so that this model is felt to be compatible with the character of student-centered thematic learning (Primandari, 2019) this is in line with Susanti, (2017). There is an interaction between students so that student learning activities can increase. Increasing student activity in groups can have an impact on student learning outcomes. In addition, through an appreciation of students, it will have a positive impact on learning outcomes and can even train students to be responsible for what they do. The reward is a feature of the cooperative model type STAD (Purwanto in Ernata 2017: 784) argues that reward is a tool to educate children so that children can feel happy because their work or deeds are rewarded, this is 
also supported by Nugroho (in Rosyid 2018: 8) that reward is an award or reward that aims to make someone more active in improving themselves and increasing their performance so that they have an impact on learning outcomes.

Students are considered successful if students can achieve learning goals. Learning objectives can be measured through learning outcomes. Gagne \& Briggs (in Baktini, 2019) argue, learning outcomes are a person's expertise that causes actions and can be seen through the behavior seen by students (learner's performance). Risnawati, (2019) Learning outcomes are points obtained by students after going through various teaching and learning processes as for other opinions, namely learning outcomes is a form of change in students from cognitive, affective, and psychomotor aspects through tests of learning material (Susanto, 2013: 5 ). Learning outcomes can also be seen based on certain criteria, this statement is in accordance with the opinion (Sudjana in Jihad, 2013: 20) The criteria for teaching success or student learning outcomes can be divided into two, namely: 1) Criteria seen from the process these criteria emphasize a dynamic process so that students can develop potential through self-study, 2) Criteria seen from the results, in addition to being viewed in terms of the process, the success of teaching is also seen in terms of results that can be seen from the overall form of behavior change. Anderson and Krathwoll distinguish the cognitive realm in 2 dimensions, namely the knowledge dimension and the cognitive process dimension (Husamah, 2018: 152). Then Anderson and Krathwoll have a collection of ways to express and expand the dimensions of knowledge such as a) factual knowledge which contains basic parts that should be known, b) conceptual knowledge, which includes explicit and implicit strategies, models or concepts, c) procedural knowledge, "knowledge of how to" do something, d) metacognitive knowledge, namely, knowledge of general awareness and knowledge of one's consciousness ( Ariyana, 2019: 8). The dimensions of knowledge and the dimensions of cognitive processes can be seen in Table 1 below.

Table 1. Knowledge dimension and cognitive process dimension

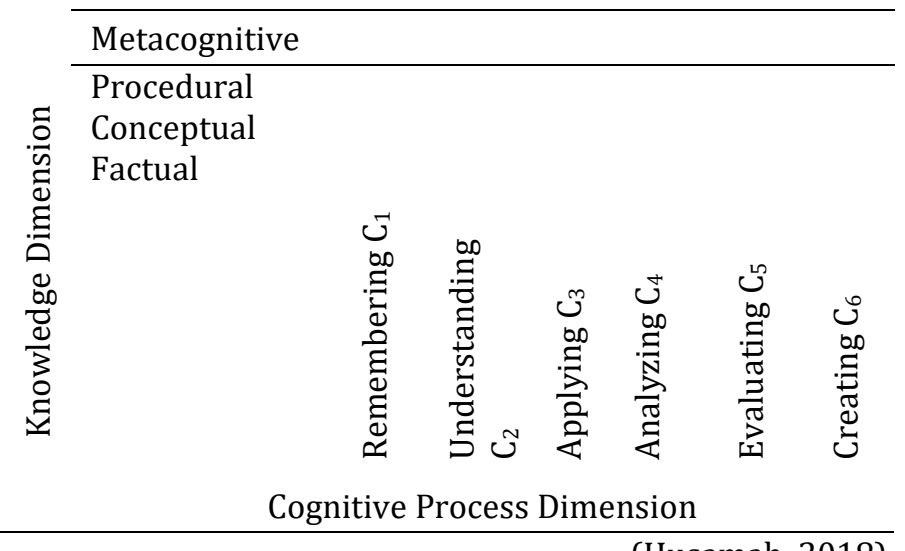

(Husamah, 2018)

Learning outcomes in this study are limited only to the cognitive aspects, namely from C3-C5. The cognitive aspect of $\mathrm{C} 3-\mathrm{C} 5$ is taken because the cognitive aspects of $\mathrm{C} 1-\mathrm{C} 2$ at this stage a person is only asked to be able to recall, mention, know something in general so that this aspect is considered easier than the cognitive aspect of C3, on the cognitive aspect of C3- C5 is a person's ability to a higher level than insight which simply requires people to be able to choose, consume or apply something. In addition, the test conducted by the OECD emphasizes students to be able to think from the C3 cognitive level to train students to think more advanced. Several studies have found that the cooperative model type STAD affects student learning outcomes, namely research conducted by Hadinata, (2017) this research uses the STAD type cooperative learning model and discusses science learning outcomes while Wahyuni, (2020) this research uses the cooperative learning model STAD type on Mathematics learning outcomes. The two researchers used the same learning model, namely the STAD cooperative learning model, but Hadinata's research, (2017) was accompanied by a discussion model at the elementary school level, and research by Wahyuni, (2020) used the STAD type cooperative model at the junior high school level (SMP) and the research results are relevant. Whereas what distinguishes this study from the two above research is that this study examines student learning outcomes with the dimensions of knowledge from the C3-C5 level and the cognitive process dimensions K1-K4 This research aims to determine the significant effect of the STAD Type Cooperative learning model on Science Learning Outcomes. 


\section{Research Method}

This research is a quasi-experimental research type with a non-equivalent post-test design (Mahrendra, 2017). The total population in this study amounted to 95 people. Sampling in this study using the intact group random sampling technique. The total sample in this study was 49 students. The method of collecting data in this study used the test method; the type of test used was a multiplechoice test (dichotomy) with one correct answer. This test consisted of 20 items. Each question item was accompanied by four answer options (options a, b, c, and d). Each item was given a score of 1 if the student answers correctly and was given a score of 0 for the wrong student. Then the scores of each item were added up to obtain a variable score on the results of the IPA. Before continuing the research, the population must first be tested for equivalence used one-way analysis of variance (ANOVA A) used the midterm test scores on the Natural Science content. The equivalence test was intended to determine whether there is a difference in the mean score of the IPA content, in addition to ensuring that the SD sampled was an equivalent SD. The equivalence test was carried out with the help of Microsoft Excel 2010 with a significance level of 5\%. Previously, the tests were used, it was necessary to carry out trials in the form of validity with biserial point correlation, reliability with KR21, difference power, difficulty index, and distractor (Mahendra, 2019). Data analysis was carried out after giving the post-test to the experimental group and the control group using descriptive statistics and inferential statistics. Data descriptions in descriptive analysis techniques in this study included mean (M), median (Me), mode (Mo), standard deviation, and variance. While inferential analysis techniques with prerequisite test analysis include normality test using the Chi-square formula, homogeneity test using the F test formula, and t-test with the polled variance formula and performed with the help of Microsoft Excel 2010.

\section{Result and Discussion}

The research was conducted at SD Gugus II, Sawan District. This research took place from 31 January 2020 to 7 March 2020, treatment was given 7 times in the experimental group and 7 times in the control group with 1 meeting for post-test in class IV SD Negeri 3 Bebetin as an experimental group and fourth grade SD students. Negeri 2 Bebetin as the control group. The results of descriptive statistical data analysis of science learning outcomes in the experimental group and the control group are presented in Table 2 below.

Table 2. Data Description Experiment Group and Control Group

\begin{tabular}{ccc}
\hline Analysis Result & Experiment & Control \\
\hline Mean & 78,96 & 75,48 \\
Median & 79,00 & 76,3 \\
Modus & 79,05 & 76,65 \\
Standard Deviation & 4,90 & 5,53 \\
Variants & 24,04 & 30,53 \\
Highest Score & 90 & 85 \\
Lowest Score & 66 & 60 \\
Range & 25 & 26 \\
Class Length & 4 & 6 \\
\hline
\end{tabular}

The results of the calculation describe that the science learning outcomes in the experimental group include the mean, namely 78.96, the median, 79.00, and the mode, 79.05. Meanwhile, the results of the calculation of science learning outcomes in the control group include the mean is 75.48, the median is 76.3 , the model is 76.65 . These data prove that the experimental group through the STAD cooperative learning model was better than the control group, namely 78.96\&gt; 75.48. These data indicate that the experimental group that was taught by applying the STAD cooperative model had a higher average score than the control group. Furthermore, the prerequisite test is obtained through the data distribution normality test and the variance homogeneity test. The data distribution normality test is intended to determine that the sample data comes from a normally distributed population so that hypothesis testing can be carried out. The data distribution normality test was carried out on the learning outcome data of the experimental group and the control group. The calculation of the data distribution normality test was obtained in the experimental group, namely 
the value of X2-count $=2.795$ \&lt; X2-table $=5.591$ at the $5 \%$ significance level with $\mathrm{dk}=2$, while the results obtained in the control group were the value of X2-count $=4.055$ \&lt; X2-table $=7.815$ at the $5 \%$ significance level. and $\mathrm{dk}=3$. This means that $\mathrm{HO}$ is accepted so that the distribution of post-test value data on learning outcomes in the experimental group and the control group is normally distributed. Furthermore, the homogeneity test of variance between the experimental group and the control group using the $\mathrm{F}$ test obtained $\mathrm{F}$-count $=1.45$ and $\mathrm{F}$-table $=4.05$ with a significance level of $5 \%$. Thus the value of F-count $<$ F-table, this means that there is no difference in variance between the experimental group and the control group (homogeneous data variance). The following is the Normality Test of Data Distribution and Homogeneity of Variants.

Table. 3. Normality Test of Data Distribution and Homogeneity of Variance (F-Test)

\begin{tabular}{|c|c|c|c|c|c|c|c|}
\hline \multirow[b]{2}{*}{ Sample } & \multicolumn{4}{|c|}{ Normality of Data Distribution } & \multicolumn{3}{|c|}{ Homogeneity of Variance } \\
\hline & $X_{\text {-count }}$ & $\mathbf{X}$-table & Information & $\begin{array}{c}\text { Variants } \\
\text { (S2) }\end{array}$ & F-count & F-table & $\begin{array}{c}\text { Informatio } \\
n\end{array}$ \\
\hline $\begin{array}{c}\text { Experiment } \\
\text { Class }\end{array}$ & 2,795 & 5,591 & Normal & 24,04 & 1,45 & 4,05 & Homogeno \\
\hline Control Class & 4,055 & 7,815 & Normal & 30,53 & & & us \\
\hline
\end{tabular}

Based on the results of testing the assumptions of data analysis, the experimental group and the control group learning outcomes were normal and homogeneous. After the data analysis assumption test results are obtained, the analysis is continued with testing the research hypothesis (H0) and hypothesis (H1). The hypothesis testing is calculated using the independent sample t-test (uncorrelated) with the polled variance formula. The standard of testing is rejected $\mathrm{H} 0$ if $\mathrm{t}$-count $>\mathrm{t}$ table, where t-table and $\mathrm{HO}$ are accepted if t-table <t-table where t table is obtained from the distribution table at the $5 \%$ significance level with degrees of freedom $d b=n 1+n 2-2$. The results of the t-test analysis are presented in Table The following 4.

Table 4. T-test Result

\begin{tabular}{ccccccc}
\hline Group & $\mathbf{N}$ & Db & Mean $(x)$ & $\mathbf{s}^{2}$ & t-count & t-table \\
\hline Experiment & 26 & 47 & 78,96 & 24,04 & & \\
Control & 23 & & 75,48 & 30,53 & 2,540 & 2,067 \\
\hline
\end{tabular}

The results of the t-test data analysis showed that the $t$-count value was 2.540 and the $t$-table value was 2.067 with $\mathrm{db}=47$ at the $5 \%$ significance level. Based on the test criteria, because $\mathrm{t}$ count\&gt; t-table, $\mathrm{H} 0$ is rejected and $\mathrm{H} 1$ is accepted. That is, there is a significant effect of science learning outcomes between groups of students who take learning with the Cooperative Type STAD model and not using the STAD Cooperative Model. The data analysis of the fourth-grade students\&\#39; learning outcomes has a significant effect between the groups of students who are taught the STAD Cooperative Type and those taught by conventional learning in the fourth-grade students of SD Gugus II, Sawan District. This review is based on calculations carried out, namely that the average grade IV student learning outcomes in the experimental group are higher than the control group and the t-test results show that the value of $t$ is greater than the $t$-table. These results indicate that the STAD-type cooperative model has a positive effect on the learning outcomes of grade IV students at SD Gugus II, Sawan District. There are differences in student science learning outcomes due to differences in treatment in the implementation of learning. Learning with the STAD Cooperative learning model makes students the center of learning, this model emphasizes collaborative activities with groups through six steps in learning. Giving treatment to the experimental group is intended so that students are involved in learning through teamwork to build cooperation, train soft skills, and thinking skills of students, with groups, students accidentally develop the ability to communicate by arguing with each other about the material being studied. Students who are taught using the STAD cooperative model show the development of better learning outcomes. During the learning activities, most of the students were actively involved in the learning process, so that when the post-test was given, the experimental group learning outcomes were higher than the control group learning outcomes. The STAD type cooperative learning model is superior because the steps in the STAD type cooperative learning model can train and improve students\&\#39; 
abilities at the cognitive level C3-C5, this is in line with Nikmah, (2016) the STAD model can create active, creative learning and fun for students during the learning process so that it will be able to arouse student enthusiasm for learning so that it will affect their learning outcomes. The following are six steps in the type of STAD cooperative learning model. The first stage of the STAD type of cooperative learning model is the delivery of goals and motivation to students, in accordance with the benefits of the STAD learning model to motivate students to help each other in mastering the skills or knowledge presented (Haris, 2019). The motivation referred to in this case is to arouse the curiosity that exists in students. Students with high curiosity students tend to always ask or ask about some things, in line with this opinion Astuti, (2020) states that motivation can make people capable do something to know about various things. Student enthusiasm can be seen when the teacher conveys the learning objectives, the students are more enthusiastic in participating in learning. The second stage is group division, at this stage students are taught to learn to be responsible, disciplined and not discriminate against friends, this activity is seen when students divide themselves into small groups of 4-5 people in an orderly manner, and group discipline is formed heterogeneously to avoid students with the same ability in one group this statement is supported by Munte, (2019) The formation of heterogeneous groups can help students work together, help each other learn the material so that all members understand what is being learned. The third stage is the presentation from the teacher, the teacher delivers material that the students should know, and then the students analyze and study the important things conveyed by the educator to increase understanding in the discussion and make it easier to understand the material to be studied. By understanding the material presented by the teacher, students can find important points to be taken into consideration with their respective groups. This activity can be seen when the teacher delivers material about the properties of magnets, students seem to focus on listening and understanding the teacher's delivery.

The fourth stage, namely learning in teams (teamwork) students are required to be able to work with groups, analyzing material related to what the teacher said at this stage students also work on Student Worksheets (LKPD), working on LKPD with groups can guide students to determine, use, analyze, find, conclude, compare, and summarize the material being learned. Each student contributes and is responsible for self and group understanding to be able to master the material being studied, this is clear when students can use the tools and materials according to the direction of the LKPD when carrying out learning activities on the material of magnetic force and gravity, students find differences ( comparing) to the treatment given to olgam money, paper and cotton, then the teacher observes, provides guidance, encouragement, and assistance if needed. In this teamwork activity, it opens opportunities for students to freely ask group members, in line with Nikmah, (2016) by asking and arguing can provide opportunities for students to express themselves. Expressing themselves can be seen when students finish answering the LKPD of each group, asked by group representatives to present and conclude the work, students answer the LKPD with enthusiasm, and display a good presentation of each group member. In the fifth stage, namely the quiz, at this stage students are not allowed to cooperate. This quiz is carried out by the teacher orally giving questions to students, the quiz given is limited. This quiz is a scramble, if the student can answer the quiz, the student is entitled to one star for one question (quiz). Wardani, (2016) states, giving quizzes is a way to train students to reflect on the material being taught, quizzes function to find out feedback and provide reinforcement for students. At this stage, students must collect the stars they get to contribute to their respective groups. This quiz is not just to get a prize or reward, but this quiz requires students both individually and in groups to be able to find, master, understand what they have learned in the third and fourth stages. Students' enthusiasm for answering the quiz can be seen in step five. The sixth stage, namely team achievement awards or rewards, rewards are prizes, which aim to make someone happy, motivated to improve learning outcomes in line with Nugroho's opinion (in Rosyid 2018: 8) that rewards are rewards, offerings, awards or rewards that mean someone is more active in fixing or increasing the performance to be achieved. This award is obtained from the number of stars received from each group member. The number of stars earned will be accumulated at the end of the sub-theme and the reward will be accepted by students at the end of the lesson. The reward is proven to be able to increase students' high interest in learning seen from the enthusiasm of students who are enthusiastic and scramble to answer quizzes and during learning activities students are actively involved in taking part in learning, especially in the fourth and fifth stages, namely learning teams and quizzes, at this stage students required to be able to understand, analyze the material provided to be able to answer the quiz given. This has a positive impact on the provision of the post-test, the value of the experimental group learning outcomes is higher than the learning outcomes of the control group. In this study, the STAD type cooperative learning model showed positive results in learning. Based on the findings in this research, it can be stated that students' 
science learning outcomes improved after participating in the STAD cooperative learning model, this indicates that there was a significant effect on science learning outcomes on class IV students in cluster II of Sawan District.

\section{Conclusion}

Based on the results of the research and discussion, it was concluded that there was a significant influence on student learning outcomes between the experimental group that was taught with the Cooperative Type STAD model and the control group that was not taught with the Cooperative Type STAD model. The difference between the experimental group and the control group shows that the STAD-type cooperative model has a positive effect on student learning outcomes compared to conventional learning. Thus, the STAD cooperative model affects student learning outcomes. The suggestions that are expected from the research that has been done are as follows. Theoretically, this research can contribute to innovative learning models to support the learning process. In addition, there are several suggestions given to related parties, namely: For teachers, teachers are advised to apply the STAD Type Cooperative learning model to improve student learning outcomes. For school principals, it is recommended to use the results of this study as a guide to guide teachers in implementing the learning process using the STAD Type Cooperative learning model to improve teacher skills in teaching and improve student learning outcomes. For other researchers, it is suggested that the results of this study can be used as a reference for researching the same variable or on different variables and pay attention to the constraints experienced in this study as a reference for developing research to be carried out.

\section{References}

Andrian, D., Wahyuni, A., Ramadhan, S., \& Novilanti, F. R. E. (2020). Pengaruh Pembelajaran Kooperatif Tipe STAD Terhadap Peningkatan Hasil Belajar, Sikap Sosial, dan Motivasi Belajar. INOMATIKA, 2(1), 65-75. https://doi.org/10.35438/inomatika.v2i1.163

Ariyana, Pudjiastuti, dkk. (2019)."Buku Pegangan Pembelajaran Berorientasi pada Keterampilan Berpikir Tingkat Tinggi". Jakarta : Direktorat Jenderal Guru dan Tenaga Kependidikan Kementerian Pendidikan dan Kebudayaan.

Astuti. (2020). Efektivitas Model Multiliterasi Kritis dengan Model Radec Terhadap Kemampuan Menulis Teks Eksplanatorium.Tersedia pada:https://ejournal.upi.edu/index.php/eduhumaniora/issue/view/1686. Diakses tanggal 20 April November 2020. https://doi.org/10.17509/eh.v12i1

Ernata, Y. (2017). Analisis motivasi belajar siswa melalui pemberian reward dan punishment di sdn ngaringan 05 kec. gandusari kab. blitar. Jurnal Pemikiran dan Pengembangan Sekolah Dasar (JP2SD), 5(2), 781-790. https://doi.org/10.22219/ip2sd.v5i2.4828

Hadinata, L. W., Utaya, S., \& Setyosari, P. (2017). “Pengaruh Pembelajaran Student Team Achievement Division dan Diskusi terhadap Hasil Belajar IPA Kelas IV SD".Jurnal Pendidikan: Teori, Penelitian, dan Pengembangan, 2(7), 979-985. http://dx.doi.org/10.17977/jptpp.v2i7.9693

Harahap, N. (2013). Penerapan Model Pembelajaran Kooperatif Tipe STAD terhadap Hasil Belajar Kognitif, Motivasi, Dan Aktivitas Belajar Siswa pada Konsep Ekosistem di MTSN Model Banda Aceh. Visipena Journal, 4(2), 57-76. https://visipena.stkipgetsempena.ac.id/?journal=home\&page=article\&op=view\&path\%5B\%

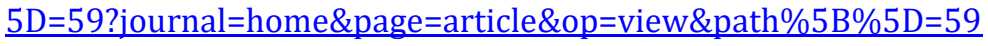

Haris, H., \& Fitriani, B. (2019). Penerapan Model Pembelajaran Kooperatif Tipe Student Teams Achievement Division (Stad) Pada Pelajaran PKn Di SMA Negeri 1 Watansoppeng. Supremasi: Jurnal Pemikiran, Penelitian Ilmu-ilmu Sosial, Hukum dan Pengajarannya, 13(1). https://doi.org/10.26858/supremasi.v13i1.10012

Husamah, dkk. (2018).Belajar dan Pembelajaran. Malang: UMM Press.

Jihad, Asep, dkk. (2013). Evaluasi Pembelajaran.Yogyakarta:Multi Pressindo Kelompok, Kerja Dosen IPA PGSD. 2018. Pendidikan IPA. Singaraja: Undiksha Press. 
Indriani. (2019). "Mendikbud: Hasil PISA Tunjukkan Perspektif Pendidikan Indonesia". Tersedia pada https://www.antaranews.com/berita/1191792/mendikbudhasil-pisa-tunjukkan-perspektif-pendidikan-indonesia (diakses tanggal 3 Desember 2019).

Karacop, A. (2017). "The Effect of Using Jigsaw Method Based on Cooperative Learning Model in the Undergraduate Science Laboratory Practices". Universal Journal of Educational Research, Vol. 5, No. 3 (hlm. 420-434). https://files.eric.ed.gov/fulltext/E]1134440.pdf

Mahendra, E.I.W. (2017). Menemukan pengetahuan baru melalui penelitian ilmiah. Mengembangkan Kemampuar Research dalam Menghadapi Era SDGs. Lembaga Penelitian dan Pengabdian Masyarakat (LPPM) IKIP PGRI Jember, pp. 12-24. ISBN 978-602-61601-1-9. http://repo.ikippgribali.ac.id/id/eprint/218/

(2019). Analisis Butir Soal. Makalah disampaikan pada Workshop Peningkatan Kompetensi Evaluasi Pembelajaran Guru SLB N 1 Buleleng, 4-7 September 2019, Singaraja. DOI: 10.13140/RG.2.2.26498.71360

Munte, B. (2019). “The Effect of Cooperative Model Jigsaw Type in Improving Students Achievement at Christian Education Subject Case: Grade XII IPA 1-2 SMA Negeri 1 Tebing Syahbandar". International Journal of English Literature and Social Sciences (IJELS), Vol. 4, No. 2 (hlm. 344350). DOI: $10.22161 /$ ijels.4.2.24

Nikmah, E. H., Fatchan, A., \& Wirahayu, Y. A. (2016). Model Pembelajaran Student Teams Achievement Divisions (STAD), Keaktifan dan Hasil Belajar Siswa. Jurnal Pendidikan Geografi, 3(3), $1-17$. online.um.ac.id/data/artikel/artikelE91D7FB9C21685AA36E47BE7A44B0CC7.pdf

Primandari, P. A., Sulasmono, B. S., \& Setyaningtyas, E. W. (2019). "Perbedaan Pengaruh Model Kooperatif Tipe TGT Dan STAD dengan Multimedia Interaktif Ceria Terhadap Sikap Sosial Dan Hasil Belajar Kognitif Pada Pembelajaran Tematik Kelas 5 SD”. Jurnal Basicedu, 3(1), 83-91. https://doi.org/10.31004/basicedu.v3i1.82

Popiyanto, Y. (2020). Kooperatif Tipe Think Pair Share terhadap Hasil Belajar Tematik Siswa Sekolah Dasar. Trapsila: Jurnal Pendidikan Dasar, 1(01), 44-54. http://dx.doi.org/10.30742/tpd.v1i01.851

Risnawati, A. D., Azmi, MP, Amir, Z., \& Nurdin, E.(2019). Development of a definition maps-based plane geometry module to improve the student teachers' mathematical reasoning ability. International Journal of Instruction, 12(3), 541-560. https://files.eric.ed.gov/fulltext/E]1220190.pdf

Rosyid, M. Z. (2018). Reward \& Punishment Dalam Pendidikan. Malang: Literasi Nusantara.

Setiawati, Asmira, dkk. (2019). Buku Penilaian Berorientasi Higher Order Thinking Skills. Jakarta: Direktorat Jenderal Guru dan Tenaga Kependidikan Kementerian Pendidikan dan Kebudayaan.

... (2018). "PISA Dan Literasi Indonesia". Tersedia pada: https://www.kemdikbud.go.id/main/blog Diakses tanggal 25 November 2019.

Susanti, Y., Wahjoedi, W., \& Utaya, S. (2017). Aktivitas Belajar Tematik Siswa Kelas V Sd Melalui Model Pembelajaran Kooperatif Tipe STAD. Jurnal Pendidikan Humaniora/Sains. https://core.ac.uk/download/pdf/267023884.pdf

Susanto, Ahmad. (2013). Teori Belajar dan Pembelajaran Sekolah Dasar. Jakarta: Mandiri.

Sutinah, S., \& Degeng, N. S. (2017). Model Pembelajaran Kooperatif Tipe Students Team Achievment Devision (STAD). In Prosiding Seminar Nasional Mahasiswa Kerjasama Direktorat Jenderal Guru dan Tenaga Kependidikan Kemendikbud 2016.

Wahyuni, Putri. (2020). "Pengaruh Pembelajaran Kooperatif Tipe Student Teams Achievement Division (STAD) terhadap Pemahaman Konsep Matematika pada Siswa Kelas VIII MTs N Pekanbaru". Tersedia pada : http://ejournal.uinsuska.ac.id/index.php/Kutubkhanah/article/view/2501. Diakses tanggal 14 Januari 2020. 